\title{
STRATEGI PEMECAHAN MASALAH OPEN-ENDED SISWA BERPIKIR KREATIF MATEMATIS TINGGI
}

\section{Hajjah Rafiah $^{1}$}

\section{STKIP PGRI Banjarmasin \\ haijahrafiah@stkipbjm.ac.id}

\begin{abstract}
ABSTRAK
Penelitian ini bertujuan untuk mendeskripsikan strategi pemecahan masalah open-ended yang digunakan oleh siswa dengan level berpikir kreatif matematis tinggi. Masalah open-ended yang digunakan adalah masalah aljabar dan geometri. Pendekatan penelitian yang digunakan adalah pendekatan kualitatif. Subjek penelitian merupakan siswa kelas V Madrasah Ibtidaiyah (MI) Sullamut Taufiq. Hasil penelitian menunjukkan bahwa strategi pemecahan masalah open-ended siswa berpikir kreatif matematis tinggi dalam memecahkan masalah aljabar adalah dengan menduga sebuah jawaban lalu memeriksanya dan kemudian menggunakan analogi atau masalah serupa untuk penyelesaian selanjutnya. Untuk pemecahan masalah geometri, siswa berpikir kreatif matematis tinggi menggunakan strategi pemecahan dengan mengubah cara pandang terhadap masalah, membagi masalah menjadi beberapa submasalah yang lebih sederhana, menemukan pola, dan menggunakan analogi untuk masalah serupa. Berdasarkan strategi yang digunakan tersebut, dapat dikatakan bahwa siswa berpikir kreatif matematis tinggi menggunakan kemampuan berpikir induktif secara analogi pada pemecahan masalah open-ended.
\end{abstract}

Kata Kunci: Strategi Pemecahan Masalah, Masalah Open-Ended, Berpikir Kreatif Matematis

\section{PENDAHULUAN}

Kehidupan manusia tidak terlepas dari aktivitas memecahkan suatu masalah, khususnya di era 4.0 seperti sekarang. Hal ini dilakukan manusia secara alami untuk memenuhi berbagai kebutuhan dan keberlangsungan hidupnya. Oleh karena itu, pemecahan masalah menjadi salah satu keterampilan yang harus diajarkan di sekolah khususnya dalam pembelajaran matematika [1]-[3]. Sejalan dengan pendapat [4] yang mengungkapkan bahwa pemecahan masalah merupakan inti dari pembelajaran matematika. Dengan kata lain, salah satu tujuan dari pembelajaran matematika adalah melatih siswa agar terbiasa menghadapi dan memecahkan masalah sehingga mampu bertahan hidup dalam keadaan yang selalu berubah dan kompetitif.

Kegiatan memecahkan masalah di sekolah dilakukan dengan merangsang siswa untuk menerima dan merespon masalah-masalah yang diajukan oleh guru dan kemudian membimbing siswa sampai pada penyelesaian. Malalui kegiatan 
memecahkan masalah siswa dilatih untuk mengklasifikasikan kondisi-kondisi yang relevan, membuat generalisasi, merumuskan rencana penyelesaian dan mengorganisasikan pengetahuan yang telah dimiliki siswa sebelumnya [5]. Artinya, dalam menemukan solusi atau penyelesaian, siswa harus menyusun pengetahuan mereka untuk mengkonstruksi pemahaman matematika yang baru. Dengan begitu, siswa akan memperoleh cara berpikir, rasa ingin tahu, ketekunan, dan keyakinan dalam situasi yang mungkin masih asing bagi mereka. Selain itu, siswa diharapkan terlatih dan mampu untuk menyelesaikan masalah-masalah dalam kehidupan dunia nyata yang akan dihadapi sepanjang hayat.

Pemecahan masalah didefinisikan sebagai keterlibatan siswa dengan tugastugas yang metode penyelesaiannya tidak mereka ketahui sebelumnya [6]. Pengertian ini mengimplikasikan bahwa ada dua jenis tugas yaitu masalah dan bukan masalah. Suatu tugas tidak dapat dikatakan sebagai masalah jika siswa sudah mengetahui prosedur penyelesaianya atau dapat diselesaikan dengan algoritma tertentu. Sama halnya dengan pendapat [7] yang menyatakan masalah sebagai situasi yang relatif baru dan kompleks, di mana siswa harus menciptakan sendiri algoritma penyelesaiannya. Artinya, dalam pemecahan masalah, siswa terlibat dalam memecahkan masalah yang bersifat non rutin. Oleh karena itu, penelitian ini mendefinisikan pemecahan masalah sebagai proses menyelesaikan masalah yang bersifat non rutin (tidak ada prosedur atau algoritma tertentu yang langsung dapat digunakan).

Masalah non rutin yang digunakan dalam penelitian ini adalah masalah openended. Masalah open-ended merupakan masalah yang memiliki lebih dari satu jawaban benar atau memiliki lebih dari satu metode penyelesaian yang benar [8], [9]. Masalah open-ended disebut juga dengan masalah terbuka atau masalah dengan banyak penyelesaian (multiple solution/multiple answer). Menurut [10] sifat terbuka dari masalah open-ended akan menghindari penekanan penyelesaian hanya pada algoritma, aturan, atau prosedur sehingga siswa akan mendapatkan pengalaman memecahkan masalah dengan berbagai jawaban benar, melihat masalah dengan cara yang berbeda, serta menemukan solusi yang paling sesuai untuk masalah tesebut.

Banyak upaya yang telah dilakukan untuk membakukan proses pemecahan masalah, salah satu tokoh perintisnya yang paling dikenal adalah Goerge Polya. Dalam bukunya "How to Solve It" [11] merumuskan langkah-langkah yang harus dilakukan oleh setiap orang untuk memecahkan masalah. Langkah- langkah tersebut adalah sebagai berikut. (1) Memahami masalah (understand the problem); (2) mengembangkan rencana dan strategi pemecahan masalah (devise a plan); (3) melaksanakan rencana/strategi (implement the plan); dan (4) mengkaji ulang pemecahan dan prosesnya (look back).

Keberhasilan seseorang dalam memecahkan masalah juga sangat dipengaruhi oleh strategi efektif yang digunakan. Berbagai alternatif strategi dalam menyelesaikan masalah diantaranya yaitu menyelesaikan masalah secara mundur/dari belakang (working backwards), menyelesaikan masalah secara langsung (acting out the problem), membuat gambar atau diagram (make a picture or a diagram), mengubah cara pandang terhadap masalah (changing your point of view), menemukan pola (find a pattern), menggunakan analogi atau masalah serupa (use a similar problems), 
menduga sebuah jawaban lalu memeriksanya (guess and check atau trial and error), menggunakan kasus yang ekstrim (considering extreme cases), menggunakan sifat simetri atau pencerminan (use a symmetry), dan membagi masalah menjadi beberapa submasalah lalu menyelesaikannya (devide into subproblems) [12], [13].

Siswa dengan kemampuan berpikir kreatif matematis tinggi ditemukan memiliki strategi khusus sehingga mampu menyelesaikan masalah open-ended [14]. Dalam memecahkan masalah, siswa banyak terlibat dalam kegiatan menantang sehingga para siswa mengalami kondisi-kondisi kreatif secara matematis melalui strategi pemecahan masalah yang mereka gunakan. Oleh karena itu, peneliti memfokuskan penelitian ini untuk menggali strategi pemecahan masalah open-ended siswa berpikir kreatif matematis tinggi.

\section{METODE PENELITIAN}

Penelitian ini adalah penelitian deskriptif eksploratif, karena peneliti ingin menggali dan memberikan gambarab tentang strategi siswa dengan kemampuan berpikir kreatif matematis tinggi dalam memecahkan masalah matematika openended. Oleh karena itu, pendekatan yang digunakan dalam penelitian ini di dominasi oleh pendekatan kualitatif, yaitu suatu pendekatan yang dilakukan dengan menggunakan pendekatan intensif baik perilaku ataupun pendekatan secara emosional, dan bukan melakukan pendekatan yang menggunakan rumus-rumus statistik.

Penelitian dilaksanakan di MI Sullamut Taufiq di Kota Banjarmasin. Pelaksanaan penelitian dilakukan pada semester genap taun pelajaran 2018/2019. Subjek penelitian dalam penelitian ini adalah dua orang siswa yang masing-masing siswa dipilih dari kelas VA dan VB. Pemilihan subjek didasarkan pada kegiatan pemecahan masalah open-ended dan wawancara mendalam terhadap siswa yang masuk dalam kategori berpikir kreatif matematis tinggi. Selanjutnya, strategi pemecahan masalah yang digunakan oleh siswa berpikir kreatif matematis tinggi dianalisis berdasarkan langkah pemecahan masalah Polya.

Setelah data diperoleh dari hasil pengumpulan data, maka dilakukan pengklasifikasian data, sehingga keakuratan data dapat diperiksa dan bila ada kesalahan dapat diperbaiki dengan jalan menjajaki kembali sumber datanya. Kemudian, proses selanjutnya adalah pengolahan dan analisis data dengan langkahlangkah yaitu reduksi data, penyajian data, dan penarikan kesimpulan/verifikasi.

\section{HASIL DAN PEMBAHASAN}

Berdasarkan hasil analisis diperoleh data tentang strategi pemecahan masalah open-ended yang digunakan oleh siswa. Subjek pertama adalah AR dan subjek kedua adalah RS yang masuk kategori berpikir kreatif matematis tinggi. Masing-masing subjek berjenis kelamin sama dan memiliki kemampuan matematika yang sama. Selain itu, faktor lain yang menjadi dasar penentuan subjek penelitian adalah kemampuan komunikasi verbal mereka sehingga memudahkan dalam proses wawancara. 
Pada pemecahan masalah aljabar, AR memulai penyelesaian dengan menuliskan penjumlahan tiga bilangan beserta hasilnya. Tiga bilangan pertama dan tiga bilangan kedua masing-masing mewakili lingkaran dengan posisi vertikal dan horisontal. Namun, yang paling penting pada penentuan bilangan-bilangan ini adalah salah satu bilangannya harus sama. Artinya, ada satu bilangan pada penjumlahan tiga bilangan pertama dan penjumlahan tiga bilangan kedua yang sama. Bilangan tersebut adalah 5 yang akan menempati lingkaran bagian tengah. Sementara, hasil penjumlahan yang dipilih adalah 10. Setelah mendapatkan formasi bilangan yang sesuai, maka selanjutnya AR menuliskan bilangan-bilangan tersebut pada lingkaranlingkaran seperti yang disajikan pada masalah. Untuk jawaban kedua, AR juga melakukan hal yang sama. Hasil penjumlahan tiga bilangan yang dipilih adalah 9 dan bilangan yang sama untuk penjumlahan bagian horizontal dan vertikal adalah 3 .
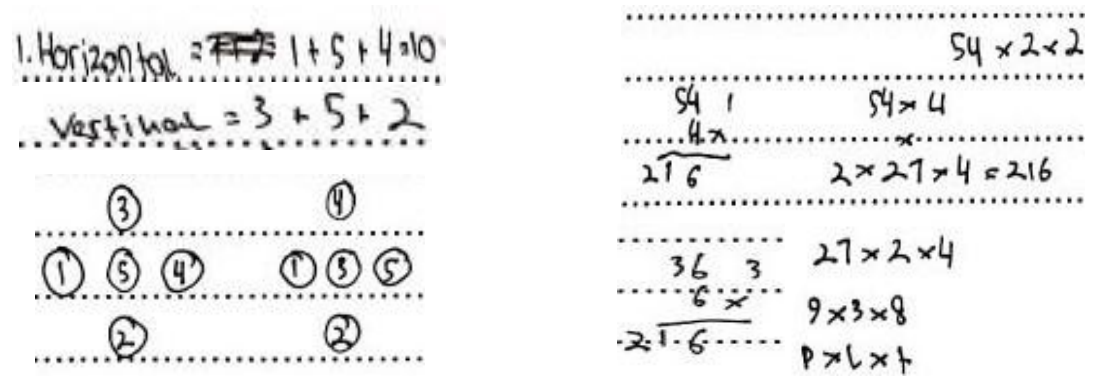

Gambar 1. Pemecahan Masalah Aljabar yang diberikan oleh AR

Pada masalah geometri, AR menentukan ukuran panjang lebar dan tinggi balok dengan cara mencari bilangan-bilangan yang hasil perkaliannya adalah 216 . AR memulai dengan perkalian dua bilangan, kemudian mengubahnya menjadi perkalian tiga bilangan. Perkalian yang ditulis oleh AR pada lembar pemecahan masalah yaitu $54 \times 4=216$. Karena, $4=2 \times 2$ maka perkalian berikutnya adalah $54 \times 2 \times 2=216$. Tiga bilangan tersebut menunjukkan masing-masing ukuran rusuk balok, dimana panjang balok adalah $54 \mathrm{~cm}$, lebar balok adalah $2 \mathrm{~cm}$ dan tinggi balok adalah $2 \mathrm{~cm}$. Dengan cara demikian, AR memberikan banyak penyelesaian dalam menentukan ukuran panjang, lebar, dan tinggi balok dengan volume $216 \mathrm{~cm}^{3}$.

Berdasarkan analisis lembar pemecahan masalah dan hasil wawancara diperoleh strategi penyelesaian yang digunakan oleh AR. Pada pemecahan masalah nomor 1, AR mensintesis masalah menjadi lebih sederhana, yaitu dengan memisahkan proses perhitungan pada bagian horizontal dan vertikal agar lebih mudah. Pada pemecahan masalah nomor 2, AR melakukan manipulasi perkalian dua bilangan menjadi perkalian tiga bilangan baru dengan menggunakan konsep faktor untuk mendapatkan ukuran panjang, lebar, dan tinggi balok.

RS memberikan dua cara penyelesaian pada masalah nomor aljabar, yaitu menggunakan trial and error dan konsep komutatif penjumlahan. Awalnya RS 
melakukan coba-coba sehingga jumlah pada lingkaran-lingkaran horisontal dan lingkaran-lingkaran vertikal adalah sama. Setelah menemukan bilangan yang sesuai yaitu 9, RS mampu dengan cepat memberikan jawaban lain. Cara yang digunakan oleh RS adalah hanya dengan menggeser atau mengubah posisi angka-angka yang sudah tersusun dalam lingkaran-lingkaran horizontal dan vertikal. Artinya, RS memahami bahwa perubahan posisi bilangan pada operasi penjumlahan tidak mempengaruhi hasil penjumlahan

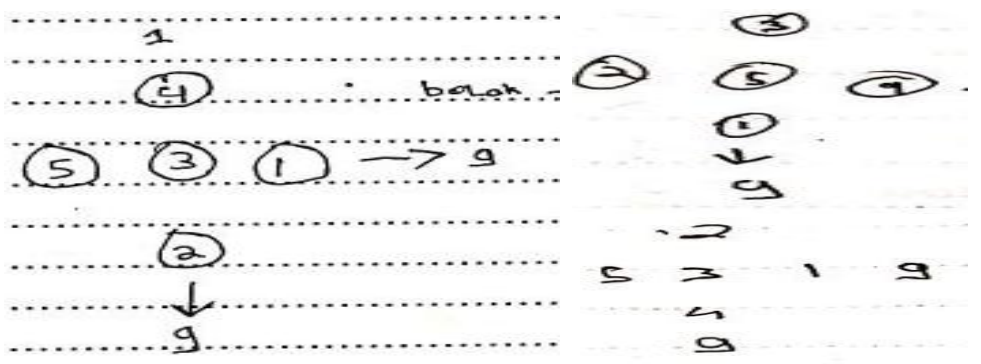

Gambar 2. Pemecahan Masalah Aljabar yang diberikan oleh RS

Pada pemecahan masalah geometri, RS awalnya menggunakan gambar balok untuk menentukan ukuran panjang, tinggi, dan lebar balok. Kemudain, menetukan perkalian tiga bilangan dengan cara menurun untuk mendapatkan volume $216 \mathrm{~cm}^{3}$. Tiga bilangan pertama yang diperoleh adalah $216 \times 1 \times 1$. Selain itu, RS juga menggunakan konsep distributif perkalian dengan cara menetukan perkalian tiga bilangan yang menghasil 216, kemudian mengubahnya menjadi perkalian dua bilangan lain dan diubah kemabli menjadi tiga bilangan berbeda. Penyelesaian yang diberikan oleh RS adalah $2 \times 18 \times 6$ untuk ukuran panjang, tinggi, dan lebar balok yang kedua. Karena $2 \times 6=12$ maka $2 \times 18 \times 6=12 \times 18$. Selajutnya, karena $18=3$ $\times 6$, maka $2 \times 18 \times 6=12 \times 18=12 \times 3 \times 6$. Cara ini memudahkan RS untuk menentukan ukuran rusuk balok yang lain dengan cepat dan mudah.

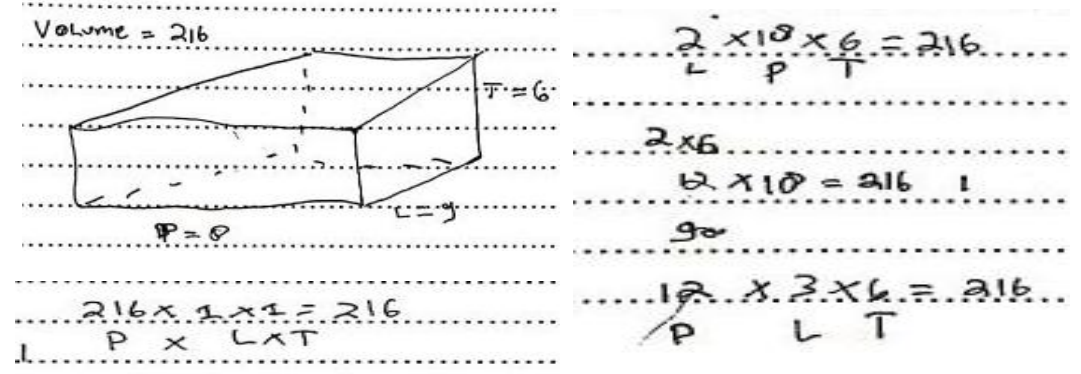

Gambar 3. Pemecahan Masalah Geometri yang diberikan oleh RS

Berdasarkan hasil analisis lembar pemecahan masalah open-ended dan kegiatan wawancara, strategi yang digunakan oleh RS pada pemecahan masalah aljabar yaitu hanya dengan menggeser atau mengubah posisi angka-angka yang sudah tersusun dalam lingkaran dimana siswa umumnya hanya menggunakan penjumlahan biasa 
untuk mendapatkan hasil yang sama. Artinya, strategi RS dalam memecahkan masalah aljabar adalah dengan menggunakan konsep komutatif penjumlahan. Pada masalah nomor geometri, RS menggunakan kombinasi konsep faktor perkalian dan sifat distributif yaitu dengan mencari perkalian tiga bilangan terlebih dahulu kemudian mendistribusikannya ke dalam bentuk perkalian dua bilangan dan dilanjutkan dengan mengubahnya lagi menjadi perkalian tiga bilangan yang berbeda dari yang pertama. Sementara siswa yang lain cenderung menggunakan dan mencari tiga bilangan langsung pada proses perkalian untuk mendapatkan hasil 216.

Tahap awal merupakan tahap memahami masalah dimana subjek sudah memahami masalah keseluruhan dapat mendeskripsikan inti pertanyaan. Pada pemecahan masalah aljabar subjek pertama mempartisi penjumlahan masing-masing lingkaran yang mewakili posisi vertikal dan horizontal. Setelah itu, subjek menentukan satu bilangan yang menunjukkan hasil akhir penjumlahan tersebut. Kemudian, subjek menentukan penjumlahan tiga bilangan yang hasilnya sesuai dengan bilangan yang telah ditentukan. Jika diurutkan sesuai langkah pemecahan masalah maka strategi yang digunakan subjek berturut-turut adalah membagi masalah menjadi beberapa submasalah yang lebih sederhana lalu menyelesaikannya, menyelesaikan masalah secara mundur, menduga sebuah jawaban lalu memeriksanya, dan kemudian menggunakan analogi atau masalah serupa untuk penyelesaian selanjutnya.

Subjek kedua memulai rencana penyelesaian masalah pertama dengan mencoba beberapa bilangan sehingga hasil penjumlahan yang diinginkan sama. Setelah menemukan formasi bilangan-bilangan yang sesuai, subjek menemukan penyelesaian lain dengan menggeser posisi bilangan-bilangan pertma sehingga mendapat formasi baru. Berdasarkan langkah-langkah pemecahan masalah, subjek kedua menggunakan strategi dengan menduga-duga sebuah jawaban lalu memeriksanya dan kemudian menggunakan analogi atau masalah serupa untuk penyelesaian selanjutnya.

Pada pemecahan masalah geometri, subjek pertama tidak langsung menentukan ukuran panjang lebar dan tinggi balok, namun menentukan perkalian dua bilangan terlebih dahulu yang hasilnya sama dengan volume balok yang diketahui. Kemudian, perkalian dua bilangan dimanipulasi menjadi perkalian tiga bilangan, sehingga diperoleh ukuran panjang, lebar, dan tinggi balok. Jawaban berikutnya hanya dengan menentukan perkalian tiga bilangan berdasarkan dua bilangan yang sudah diketahui. Berdasarkan langkah-langkah pemecahan masalah yang digunakan, maka strategi yang digunakan subjek pertama adalah mengubah cara pandang terhadap masalah, membagi masalah menjadi beberapa submasalah yang lebih sederhana lalu menyelesaikannya, menemukan pola, menggunakan analogi atau masalah serupa.

Subjek kedua memecahkan masalah geometri dengan menggunakan bantuan gambar terlebih dahulu. Setelah itu, subjek melakukan manipulasi aljabar dengan 
menentukan perkalian tiga bilangan, kemudian mengubahnya menjadi perkalian dua bilangan lain dan diubah kembali menjadi tiga bilangan berbeda. Ukuran rusuk balok selanjutnya diperoleh dengan mengubah faktor-faktor perkalian tersebut. Berdasarkan langkah-langkah pemecahan masalah yang digunakan, maka strategi yang digunakan subjek kedua adalah menggunakan gambar sebagai stimulus awal, mengubah cara pandang terhadap masalah, membagi masalah menjadi beberapa submasalah yang lebih sederhana lalu menyelesaikannya, menemukan pola, dan menggunakan analogi atau masalah serupa.

Secara umum, siswa berpikir kreatif matematis tinggi strategi bekerja sesuai langkah-langkah pemecahan masalah yang dikemukakan oleh Polya. Sementara untuk memecahkan masalah aljabar, siswa berpikir kreatif matematis tinggi menggunakan beberapa strategi yang sama yaitu menduga sebuah jawaban lalu memeriksanya dan kemudian menggunakan analogi atau masalah serupa untuk penyelesaian selanjutnya. Untuk pemecahan masalah geometri, siswa berpikir kreatif matematis tinggi menggunakan strategi pemecahan masalah dengan mengubah cara pandang terhadap masalah, membagi masalah menjadi beberapa submasalah yang lebih sederhana lalu menyelesaikannya, menemukan pola, dan menggunakan analogi atau masalah serupa. Setiap strategi yang digunakan sesuai dengan jenis strategi pemecahan masalah yang dikemukakan oleh [13]. Berdasarkan hasil pemecahan kedua masalah open-ended, siswa berpikir kreatif matematis tinggi menggunakan kemampuan berpikir induktif secara analogi. Hal dapat dipengaruhi oleh kemampuan penalaran siswa berpikir kreatif matematis tinggi yang juga tinggi [14].

Perbedaan juga ditemukan pada strategi pemecahan masalah yang digunakan oleh siswa berpikir kreatif matematis tinggi, namun tidak signifikan. Pada pemecahan masalah aljabar, subjek pertama menggunakan strategi pemecahan dengan menyelesaikan masalah secara mundur. Sementara, untuk pemecahan masalah geometri subjek kedua menggunakan gambar atau diagram untuk memulai langkah penyelesaian. Perbedaan strategi ini mengindikasikan bahwa setiap strategi bersifat relatif antara satu dengan yang lain Karena masing-masing strategi pemecahan tidak ditujukan untuk memecahkan semua jenis masalah [15]. Dengan kata lain, untuk menyelesaikan suatu masalah dapat dipecahkan dengan satu strategi, tetapi pada kondisi lain menuntut penggunaan beberapa strategi.

Hal menarik lain dalam penelitian ini juga ditunjukkan oleh siswa dengan kemampuan berpikir kreatif matematis tinggi yang dapat menjawab pertanyaan dengan benar. Meskipun siswa dikategorikan sebagai siswa dengan kemampuan berpikir kreatif matematis tinggi, namun siswa belum mampu mengembangkan estetika matematika saat memecahkan masalah. Hal ini dikarenakan siswa sangat tergantung pada pengetahuan prasyarat [7]. Siswa menyajikan pemecahan masalah dengan sangat jelas, namun mereka tidak mampu mengekspresikan kesederhanaan, 
struktur, dan konsep matematika dalam pemecahan masalah yang diberikan. Selain itu, ada beberapa kekurangan pada solusi-solusi yang diberikan tersebut.

\section{SIMPULAN}

Strategi pemecahan masalah open-eded yang digunakan oleh siswa berpikir kreatif matematis tinggi dalam memecahkan masalah aljabar adalah dengan menduga sebuah jawaban lalu memeriksanya dan kemudian menggunakan analogi atau masalah serupa untuk penyelesaian selanjutnya. Adapun pada pemecahan masalah geometri, siswa berpikir kreatif matematis tinggi menggunakan strategi pemecahan masalah dengan mengubah cara sudut pandang terhadap masalah, membagi masalah menjadi beberapa submasalah yang lebih sederhana lalu menyelesaikannya, menemukan pola, dan menggunakan analogi atau masalah serupa. Selain itu, penggunaan strategi tambahan masing-masing siswa yaitu menyelesaikan masalah secara mundur untuk pemecahan masalah aljabar dan menggunakan gambar atau diagram untuk pemecahan masalah geometri. Dengan demikian, dapat dikatakan bahwa siswa berpikir kreatif matematis tinggi menggunakan kemampuan berpikir induktif secara analogi dalam memecahkan masalah open-ended.

Dalam pendekatan tradisional, pembelajaran matematikan bertujuan untuk membuat siswa mencapai jawaban yang benar dengan cara yang sependek dan secepat mungkin. Namun, hal yang lebih penting dilakukan adalah menghadapkan siswa dengan berbagai pengalaman menarik dalam memecahkan masalah. Melalui hasil penelitian ini diharapkan guru dapat mendorong para siswa siswa untuk memahami masalah secara keseluruhan dan mengembangkan teknik atau strategi pemecahan mereka sendiri. Cara yang dapat dilakukan adalah dengan memberikan masalah open-ended yang dikombinasikan dengan pengalaman dan minat masingmasing siswa. Tujuannya tidak lain adalah untuk mengembangkan kemampuan berpikir kreatif siswa sejak dini.

\section{DAFTAR RUJUKAN}

[1] J. Lithner, "Learning mathematics by creative or imitative reasoning," in Selected Regular Lectures from the 12th International Congress on Mathematical Education, 2015, pp. 487-506.

[2] C. Voica and F. M. Singer, "Creative contexts as ways to strengthen mathematics learning," Procedia-Social Behav. Sci., vol. 33, pp. 538-542, 2012.

[3] H. Rafiah, "Berpikir Kreatif dalam Pemecahan Masalah Matematika," in Seminar Matematika dan Pembelajarannya Fakultas Matematika dan Ilmu Pengetahuan Alam Universitas Negeri Malang, 2015, pp. 321-325.

[4] Subanji, Pembelajaran Matematika Kreatif dan Inovatif. 2013.

[5] H. Hudojo, "Pengembangan kurikulum dan pembelajaran matematika." Malang: UM Press, 2005.

[6] N. C. of T. of Mathematics, Principles and standards for school mathematics, vol. 1. National Council of Teachers of, 2000. 
[7] E. Aizikovitsh-Udi, "The extent of mathematical creativity and Aesthetics in solving problems among students attending the mathematically talented youth program," Creat. Educ., vol. 5, no. 04, p. 228, 2014.

[8] E. Levenson, "Exploring collective mathematical creativity in elementary school," J. Creat. Behav., vol. 45, no. 3, pp. 215-234, 2011.

[9] H. Rafiah and A. Ekawati, "Misconceptions of the Students with High Mathematical Creative Thinking Level in Solving the Geometric Shapes Problems," in 5th SEA-DR (South East Asia Development Research) International Conference 2017 (SEADRIC 2017), 2017.

[10] M. Nadjafikhah, N. Yaftian, and S. Bakhshalizadeh, "Mathematical creativity: some definitions and characteristics," Procedia-Social Behav. Sci., vol. 31, pp. 285-291, 2012.

[11] G. Polya, "How to solve it second edition." New Jersey: Princeton University Press, 1973.

[12] T. Herman, "Strategi Pemecahan Masalah (Problem Solving) Dalam Pembelajaran Matematika," Makalah. Tidak Diterbitkan, 2000.

[13] Syahlan, "Sepuluh Strategi Dalam Pemecahan," vol. 4, pp. 358-369, 2017.

[14] C. Sa'dijah, H. Rafiah, M. Gipayana, A. Qohar, and L. Anwar, "Asesmen Pemecahan Masalah Open-Ended Untuk Mengukur Profil Berpikir Kreatif Matematis Siswa Berdasar Gender," Sekol. Dasar Kaji. Teor. dan Prakt. Pendidik., vol. 25, no. 2, pp. 147-159, 2017.

[15] D. Ayuningrum, "Strategi Pemecahan Masalah Matematika Siswa SMP Ditinjau Dari Tingkat Berpikir Geometri Van Hiele," Kreano, J. Mat. Kreat., vol. 8, no. 1, pp. 27-34, 2017. 